\title{
La objeción de conciencia en el Derecho Chileno
}

\section{José Ignacio Nuñez Leyva*}

\section{Who cares if one more light goes out well, I do. ${ }^{1}$}

En 1914 el portentoso -y díscolo compulsivo- Vicente Huidobro, artista principalmente dedicado a la poesía, escribió en uno de sus textos llamado Non Serviam:

"Y he aqui que una buena mañana, después de una noche de preciosos sueños y delicadas pesadillas, el poeta se levanta y grita a la madre Natura: Non serviam. Con toda la fuerza de sus pulmones, un eco traductor y optimista repite en las lejanías: «No te serviré». La madre Natura iba ya a fulminar al joven poeta rebelde, cuando éste, quitándose el sombrero y haciendo un gracioso gesto, exclamó: "Eres una viejecita encantadora». Ese non serviam quedó grabado en una mañana de la historia del mundo. No era un grito caprichoso, no era un acto de rebeldía superficial. Era el resultado de toda una evolución, la suma de múltiples experiencias. El poeta, en plena conciencia de su pasado y de su futuro, lanzaba al mundo la declaración de su independencia frente a la Naturaleza”.

Para un abogado de profesión, docente por vocación, investigador por pasión, escritor de día domingo, pero poco talentoso en todos y cada uno de esos ámbitos (como quién escribe este comentario) lo recién citado resulta una de las más bellas aproximaciones a la Objeción de Conciencia: Non Serviam.

Con todo, alguien ilustrado, puede -con rotundidad- disentir de tal aproximación, pero me apuesto (algunos) de mis papeles a que desde hace algunos años tal institución ha ido incrementando su importancia, al punto de que en el futuro cercano se convertirá en uno de los dispositivos jurídicos, ojalá derecho

\footnotetext{
*La Pontificia Universidad Católica de Chile (Chile).jinunez@uft.cl
}

1 Bennington, Chester, One more light, 2017 
fundamental, más relevante, empleado y estudiado al interior de los "Estados Constitucionales de Derecho". Y es que el prototipo de Norma Fundamental que promueve esta modalidad del "Imperio del Derecho" trastoca, pienso, incluso el concepto de Derecho. Tal como en múltiples obras el maestro italiano Mauro Barberis lo ha sostenido, implica una "Tercera Teoría del Derecho", en contraste con los Positivismos y los Iusnaturalismos.

Esa aventurada afirmación, deriva entre otras cosas de que el hoy denominado "Iusconstitucionalismo" erige sobre la fantasía piramidal de los apóstoles de Kelsen una Torre de Babel, donde protagonistas y antagonistas son candidatos a alquimistas que conviertan sus preceptivas morales en normas jurídicas, pero que rebotan con el horizonte de posibilidades de la democracia pues tal solamente permite conjurar mínimos comunes y no maximalismos imperativos. Tal es la traducción jurídica del pluralismo y de su pariente de mejor estirpe: el constructivismo. Más aún en épocas de Globalización y Anti-Globalización.

Por eso, la eximición -inspirada en convicciones- de obligaciones impuestas por los ordenamientos jurídicos no puede ser abandonada a los sismos vocacionales ni a la violencia medieval del Derecho a Resistencia. Merece el empeño de ser abordada en perspectiva científica. Esfuerzo que agradecerá cada individuo, pero también el Estado de Derecho.

La obra de la jurista chilena Betzabé Araya Peschke no elude tal desafío. Lo encara y sin vacilaciones. Más aún lo hace dentro de un ágora desfavorable. A propósito de una ley de su país que despenalizaba el aborto (solamente) en tres causales, el Tribunal Constitucional Chileno despachó las polémicas sobre la Objeción de Conciencia en tan siquiera una página. Y, con los argumentos que permite una carilla, resolvió la candente disputa acerca de la capacidad de las personas jurídicas para plantear argumentos en base a sus convicciones. Valgan mayores méritos, entonces, para la autora.

En fin, un comentario ha de ser una sinopsis, más no un índice. Por eso, a efectos de recomendar a los lectores la revisión de esta obra, me permito emplear algunas sílabas que antes utilicé para referirme a ella.

La Fe de algunas personas no las lleva a evangelizar. Las conduce a defender el derecho a escoger entre creer, no creer y en qué creer, además de la garantía de comportarse de acuerdo a tal decisión. 
La valía de este trabajo se pondera también -y especialmente- en perspectiva científica. Sus páginas revelan un excelente esfuerzo por aplicar de manera crítica la teoría de los Derechos Fundamentales a una institución generalmente abandonada en las áridas tierras de lo que Paolo Grossi llamó "Mitología Jurídica". Empeño que conduce a tesituras disruptivas con la doctrina acreditada. En una frase, aquí se defiende una postura controversial: la objeción de conciencia -en el sistema chileno- deriva del derecho fundamental a la libre manifestación de las creencias y como tal, tiene como titulares a las personas, no agrupaciones o instituciones.

En fin, este libro merece ser tenido en cuenta pues encara un tema preterido, minusvalorado e inadecuadamente abordado. Tal vez a eso se refería el mismo artista citado en las primeras líneas de este comentario cuando decía: Hemos aceptado, sin mayor reflexión, el hecho de que no puede haber otras realidades que las que nos rodean, y no hemos pensado que nosotros también podemos crear realidades en un mundo nuestro, en un mundo que espera su fauna y su flora propias. Flora y fauna que sólo el poeta puede crear, por ese don especial que le dio la misma madre Naturaleza a él y únicamente a él. Y seguramente la obra que comento evoca las palabras transcritas porque alguna vez califiqué a la autora de este libro como una "Díscola Compulsiva".

\section{Bibliografía}

Libro: La objeción de conciencia en el Derecho Chileno

Autor: Betzabé Patricia Araya Peschke

Editorial: Libromar

Año: 2017 
